Discourses of sameness:

\section{Expressions of nationalism in}

newspaper discourse on French

urban violence in 2005
Discourse \& Society

2014, Vol. 25(3) 315-340

(C) The Author(s) 2014

Reprints and permissions:

sagepub.co.uk/journalsPermissions.nav DOI: $10.1|77 / 09579265| 35 \mid 9533$

das.sagepub.com

\title{
Laura Costelloe
}

University of Limerick, Ireland

\begin{abstract}
November 2005 saw a significant flashpoint in the long-running history of tensions between minority groups and those in power in France: two teenagers, allegedly while hiding from the police, were electrocuted in a Parisian electrical sub-station, which was the catalyst for the unprecedented spread of violent riots across banlieues, or urban districts, in French cities lasting for a number of weeks. Mindful of the printed news media as important sites of ideology production, this study contributes to a growing body of work on newspaper representation of the banlieues, with a focus on the particularly traumatic events of November 2005. This article examines French newspaper representations of urban violence in 2005 using a critical discourse analytical approach, focusing on how the scenes of violent rioting prompted media discussions pertaining to French national identity. It argues that national identity and expressions of nationalism are defined in an exclusionary way, and that a discourse of sameness constructs symbolic boundaries between 'us' and 'them'. The research suggests that in its reaction to the challenging events of November 2005, the printed news media adopts strategies which 'other' immigrant minorities and those living in the banlieues. Inhabitants of the banlieues are depicted as being outside the borders of the homogenously constructed French society in order to explain the violent scenes and ultimately uphold relations of discrimination and social dominance.
\end{abstract}

\section{Keywords}

Banlieues, discourse analysis, France, French urban violence, immigrants, national identity, nationalism, newspaper discourse, power

\footnotetext{
Corresponding author:

Laura Costelloe, School of Languages, Literature, Culture and Communication, University of Limerick, Limerick, Ireland.

Email: laura.costelloe@ul.ie
} 


\section{Introduction}

This article analyses expressions of national identity in French newspaper discourse reporting on urban violence in France in 2005, incidents which represent a significant flashpoint in a long-running history of tensions between minority groups and those in power in France. More specifically, this study investigates the discursive and linguistic strategies used to construct discourses of sameness which assume in-group homogeneity and consequently exclude minority out-groups. Mindful of the role of the media as key ideological brokers, reproducers and maintainers of the dominant social order (Allan, 1998; Bishop and Jaworski, 2003; Fairclough, 1995; Hartley, 1982; Kelly-Holmes and O'Regan, 2004 Van Dijk, 1988), this study proceeds from the theoretical departure point that news discourse is inherently ideological - and consequently powerful - and analyses how newspaper discourse on French urban violence in 2005 is used to uphold unequal relations of social dominance in French society.

It has been argued that media discourse rarely tends to favour minority social groups, and it has also been observed that 'the mainstream media have never granted an arena for various minorities [...] to participate in socio-political decision making and public discussion' (Pietikäinen, 2001: 643-644). Typically, news discourse is created by the majority and for the majority, with the implicit and/or explicit exclusion of and discrimination against linguistic, religious, cultural or ethnic minorities. The printed news media are the selected data source for this study, recognised as enjoying a privileged and prestigious position in modern societies (Caldas-Coulthard, 2007). Most frequently, newspapers reflect the ideological positions of powerful people and organisations (Van Dijk, 1996). Therefore, journalists' choice of language - and consequently their discourse - tends to favour existing social positions of power, to the extent that Van Dijk (1998: 180) maintains that 'the ideologies that are most prominent in the media are largely those of the élites'. Newspapers occupy an important role, representing regular leisure reading and a source of information for many people on a daily basis; the privileged status of news discourse in modern societies leads Richardson (2007: 13) to conclude that 'the language of the news media needs to be taken very seriously'.

Particular attention is paid in this study to the discursive construction of French national identity, and to identifying the discursive means by which an 'us' (in-group) and 'them' (out-group) are created in French society. The positioning of immigrant minorities and those living in the banlieues (approximately translated as 'suburbs', but carries a particular connotation in the French context) ${ }^{1}$ vis-a-vis dominant and mainstream French society is questioned, and analysis focuses on the expression of discourses of sameness as within this order of discourse certain assumptions are made with regard to both the in-group and the out-group. A number of other studies have considered how discursive othering is achieved through the creation of in- and out-groups both in French (e.g. Tekin, 2010) and in other contexts (e.g. Crawford, 2011; Erjavec, 2001; Krzyżanowski and Wodak, 2008; Neiger and Rimmer-Tsory, 2013; Oktar, 2001; Van Dijk, 2006). The current discussion draws on these and other studies to argue that emphasis on positive characteristics of the Self and distance from negative characteristics of the Other permits a clear distinction to be drawn between the French people (us) and the immigrant minorities living in the banlieues (them). Additionally, previous studies have examined discursive strategies in relation to news reporting on civil disorder both in the 
French context (e.g. Garcin-Marrou, 2007; Peeters, 2010, 2012) and in other incidents of protest/civil disobedience (e.g. Cohen, 1972; Fang, 1994; Fowler, 1991; Fowler et al., 1979; Hart, 2012; Neveu, 2002; Simmons and Lecouteur, 2008; Thetela, 2001; Van Dijk, 1989). This study investigates a context which has heretofore received relatively little academic attention in the English language, and the focus on the role of the discursive construction of national identity as a means of excluding inhabitants of the banlieues from membership of the imagined French community marks a departure from other studies examining representations of urban violence in France.

\section{Contextualisation: The 2005 riots and news reporting on the banlieues}

Frustrations at social inequalities have resulted in heightened tensions among young people in the banlieues and majority French society and this has been manifested in relatively frequent outbreaks of civil disorder since the early 1980s. Beginning with violent outbreaks in Les Minguettes (Lyon) in 1981, throughout the 1980s and 1990s there were relatively regular scenes of violence in the suburbs, including Vaulx-en-Velin (1990), Dammarie-les-Lys (1993, 1997), Nanterre (1995), Toulouse (1998), Vauvert dans le Gard (1999), Lille (2000), Les Yvelines (2002) and Nimes (2003). Scenes typically involved confrontations between groups of youths and the police, as well as the burning of cars and buildings, looting and fights involving large numbers of people (for additional detail, see Kokoreff and Lapeyronnie, 2013; Mucchielli, 2009).

On 27 October 2005, two teenagers - Zyed Benna (age 17), the youngest of a family of six children of Tunisian descent, and Bouna Traoré (age 15), from a family of 11 children of Mauritanian origin - were killed by electrocution when they climbed a fence and entered the area surrounding a power transformer in the Parisian suburb of Clichy-sous-Bois. It was alleged that the youths went into the power station to escape a police chase, although this version of events has been questioned. ${ }^{2}$ News of their deaths was the catalyst for violent riots throughout all of France. The riots were initially limited to Clichy-sous-Bois and the surrounding areas of Montfermeil; however, from 31 October there was a progressive spread of civil disorder to other Parisian regions and throughout the rest of the country. Within days, violent scenes had erupted in Lille, Toulouse, Strasbourg, Roubaix and Bordeaux, and at its peak 300 communes in France were affected, mainly outside Paris. By 17 November, the violence and burned cars had returned to 'normal levels', according to the Ministry of the Interior. In terms of material damage, approximately 10,000 cars and 30,000 rubbish bins had been burned; hundreds of public buildings had been attacked - mainly schools, although town halls and police stations were also targeted (Mucchielli and Aït-Omar, 2006: 14).

The events in 2005 were unprecedented both in terms of scale and duration: for the first time, rioting had spread outside the immediate spatial surroundings of a particular banlieue, and an incident in Paris prompted violent reactions in neighbourhoods throughout France. Furthermore, the civil disturbances in 2005 lasted for close to three weeks, which is considerably longer than any previous incident. The extreme nature of the events of 2005 prompted an extensive amount of media coverage, and the question of the status of the banlieues and their inhabitants occupied the news pages in the days, weeks and months following the traumatic scenes. 


\section{News reporting on the banlieues}

A number of commentators (e.g. Collovald, 2001; Garcin-Marrou, 2007; Hargreaves, 1996; Levasseur, 2010; Moirand, 2010; Sedel, 2009) have observed the role played by the media in the gradual discursive repositioning of the banlieues as peripheral spaces distinct from the rest of French society and the inhabitants of the suburbs - particularly les jeunes [young people] - as representing a threat to law and order. Hargreaves (1996: 607) emphasises the 'central role' of the mass media in the reconfiguration of the word 'banlieue' as 'a synonym of alterity, deviance, and disadvantage'. Thus, in media, popular and political discourse, the word banlieue (along with the quasi-synonymous terms quartier and cité) have come to signify neighbourhoods with a large concentration of immigrants, comparatively high unemployment rates, ethnic diversity and outbreaks of civil unrest. Sedel (2009: 29-33) analyses media representations of the suburbs and their inhabitants, and identifies how the initial focus in the 1960s was on the quartiers as 'une catégorie non constituée' [an object of curiosity and fear] as journalists sought to define and label these new neighbourhoods. In the 1970s, immigrants in the banlieues became more visible as social actors in the media, particularly due to the economic downturn and the prevalence of industrial strikes in factories and mines where many inhabitants of the suburbs had worked. From the 1980s onwards, Sedel (2009: 38) suggests, media representations of the suburbs increasingly focused on the 'irruption d'un "probleme»' [the emergence of a 'problem'] and in their reporting on urban violence the press used expressions such as 'banlieue chaude' ['hot suburb'], 'rage' ['rage'], 'haine' ['hate'] etc. Consequently, from the mid-1990s, 'la «violence» devient une catégorie dominante d'interprétation des "problèmes de banlieue 》 dans les discours médiatiques et politiques' ['violence becomes a dominant category in media and political discourse for interpreting the 'problems of the suburbs'] (Sedel, 2009: 51). Similarly, Collovald (2001: 104) traces press reporting on urban violence and notes a discursive shift from descriptions of 'des désordres sociaux' ['social disorder'] to 'la violence urbaine' ['urban violence']. It is within the above-discussed context that the analysis of discourses of sameness in news reports on the 2005 riots in France must be understood. Prior to outlining the linguistic and discursive means by which this discourse is expressed, focus now turns to the data and methodology used for this study.

\section{Data and methodology}

\section{Data}

The corpus of texts used for this study is summarised in Table 1: the corpus is comprised of 16 articles from the French press reporting on the death of teenagers Bouna Traoré and Zyed Benna and the ensuing widespread urban violence throughout France. Articles were selected from four French newspapers (introduced in the following paragraph) using the following search terms: banlieue/s and émeutes/s [riot/s]. Keyword searches were limited to articles published between 27 October 2005 and 30 June 2006; these dates were specified in order to ensure that coverage of the catalytic incident which prompted the outbreak of violence - the death of the teenagers - as well as the urban violence witnessed throughout France in November 2005 were included in the analytical 
Table I. Corpus of texts used.

\begin{tabular}{|c|c|c|c|}
\hline & Title & Source & Date of publication \\
\hline I & La boîte de Pandore de Sarkozy & L'Humanité & 3 November 2005 \\
\hline 2 & Banlieues : vingt-cent ans après & Le Figaro & 4 November 2005 \\
\hline 3 & Banlieues : renvoyez l'ascenseur & Le Figaro & 8 November 2005 \\
\hline 4 & État d'urgence : fini le consensus & Ouest France & 16 November 2005 \\
\hline 5 & Discriminations & L'Humanité & 26 November 2005 \\
\hline 6 & Après le choc & Le Monde & 29 November 2005 \\
\hline 7 & $\begin{array}{l}\text { Les « racailles de France » affichent } \\
\text { leur colère }\end{array}$ & Le Monde & 10 December 2005 \\
\hline 8 & La République muette & Ouest France & 3 December 2005 \\
\hline 9 & Tourner la page & Ouest France & 23 December 2005 \\
\hline 10 & $\begin{array}{l}\text { L'État refuse de payer les dégâts des } \\
\text { violences urbaines }\end{array}$ & Le Monde & 26 December 2005 \\
\hline 11 & Immigration familiale : les faits & Le Monde & 5 January 2006 \\
\hline 12 & $\begin{array}{l}\text { Banlieues : le rôle des «grands frères» } \\
\text { en cause }\end{array}$ & Le Figaro & II January 2006 \\
\hline 13 & $\begin{array}{l}\text { Le gouvernement échoue sur la } \\
\text { croissance }\end{array}$ & L'Humanité & I3 February 2006 \\
\hline 14 & $\begin{array}{l}\text { Une journée consacrée à la vie des } \\
\text { jeunes }\end{array}$ & Ouest France & I April 2006 \\
\hline 15 & Montfermeil, sept mois après & L'Humanité & 31 May 2006 \\
\hline 16 & $\begin{array}{l}\text { La carte des émeutes de novembre } \\
2005 \text { confirme le profond malaise des } \\
\text { immigrants africains }\end{array}$ & Le Figaro & 29 June 2006 \\
\hline
\end{tabular}

sample. The expanded time frame allows for reflection and analysis in the months following the riots, while also offering insights into the representation of urban violence and the banlieues generally in the French media. All articles from the selected news sources were collected, and the 16 articles summarised in Table 1 were randomly selected to provide a broad corpus of texts for analysis.

Texts were sourced from three national daily newspapers (Le Figaro, L'Humanité and Le Monde) and one regional daily newspaper (Ouest France). The news sources represent a cross-section of French daily national/regional newspapers and are reflective of a wide variety of political and ideological perspectives: Le Monde, Le Figaro, L'Humanité and Ouest France exemplify, respectively, centre/centre-left, centre-right, left and regional standpoints.

\section{Methodological approach: Critical discourse analysis}

The critical discourse analysis (CDA) framework used for the current study is that of Fairclough (1992, 1995), although the work of other discourse analysts - principally Wodak (Wodak et al., 2009) and Van Dijk (1988) - is also incorporated, mainly at the level of text analysis. In particular, the notion of 'strategies', as proposed by Wodak et al.'s (2009) 'discourse historical approach' to CDA, is incorporated into the analytical 
discussion below. Defined as 'a more or less intentional plan of practices (including discursive practices) adopted to achieve a particular social, political, psychological or linguistic goal' (Reisigl and Wodak, 2009: 94), Wodak et al. (2009) propose five strategies by which national identity is imagined in discourse: constructive, perpetuation, justification, transformation and dismantling/destructive strategies. The first - constructive strategies - is of most relevance to the current study, as such strategies attempt 'to construct and to establish a certain national identity by promoting unification, identification and solidarity, as well as differentiation' (Wodak et al., 2009: 33). Constructive strategies are therefore useful for identifying and naming the discursive means by which the orders of discourse (Fairclough, 1995) determining interpretations of French national identity are expressed in the corpus of texts examined.

In particular, this article focuses on the choice of lexis in the articles in the corpus created for this study, mindful that within a CDA framework, 'language is treated as a system of lexico-grammatical options from which texts/authors make their choices about what to include or exclude and how to arrange them' (Benwell and Stokoe, 2006: 108). The identification of patterns of language use reveals how, to cite Chouliaraki and Fairclough (1999: 140), 'the social is built into the grammatical tissue of language'. Specifically, the analysis below focuses heavily on pronoun usage, given that 'pronoun systems are a representation of social relations, [...] they are part of the mechanisms for reproducing the orders of power', and thus they can have implications with regard to power, distance, formality, solidarity, intimacy and casualness (Fowler, 1991: 99). Fairclough (2001: 106) considers the use of 'we' in newspaper discourse, particularly newspaper editorials, and argues the following in relation to editorials:

The editorial uses (as editorials often do) the so-called 'inclusive' we, inclusive that is of the reader as well as the writer, as opposed to the 'exclusive' we, which refers to the writer (or speaker) plus one or more others, but does not include the addressee(s). The newspaper is speaking on behalf of itself, its readers [...]. In so doing, it is making an implicit authority claim $[\ldots]-$ it has the authority to speak for others.

Thus, the use of 'we' can serve to personalise a text, whether in terms of excluding or including readers, although Fowler (1991: 189) argues that any suggestions of inclusiveness are 'phoney': newspapers construct themselves both as having the implicit authority to tell readers, the government, etc. what to do, and to speak on their behalf, in a form of 'simulated personal address' (Fairclough, 2001). Following other studies which have similarly focused on the examination of pronouns in the discursive construction of identity (e.g. De Cillia et al., 1999; Dekavalla, 2010), the analysis below pays particular attention to the use of pronouns in the analytical sample and shows how the personal pronouns nous and on ['we'] are used by the French press (particularly in the editorial genre of the news article) to speak to and for the French people, and by so doing news texts often assume national singularity and homogeneity and create what has been labelled discourses of sameness.

Also of significance for analysing interpretations of French national identity in news articles on the 2005 riots is the use of modal expressions in journalistic discourse. Considered by Fairclough (1992: 160) as a 'major dimension of discourse', Simpson 
(1993: 47) offers the following definition: 'modality refers broadly to a speaker's attitudes, or opinion about, the truth of a proposition expressed by a sentence. It also extends to their attitude towards the situation or event described by a sentence'. Regarding the significance of modality to the critical analysis of news discourse, modality reveals relations of authority and/or power which the creators of discourse purport to hold over their readers, particularly with regard to the representation of reported happenings or beliefs as categorical truths or facts. Thus, the current study considers the ideological implication of how expressions of modality are used to establish either truths or certainty with regard to the representation of people and events, and the various degrees of obligation imposed on French society by the creators of the discourse examined. Modality plays an important role in constructing obligations regarding what French identity 'should' or 'must' be, while at the same time excluding minority communities in the banlieues from this interpretation.

The analysis which follows identifies the expression of a discourse of sameness as one of the dominant orders of discourse expressed in news reporting on the 2005 riots in France. Three supporting discourses have been identified, which we have labelled discourses of (i) continuity, (ii) republicanism and (iii) nationalism, all of which assume in-group homogeneity and construct a particular interpretation of French identity based on a common past which is grounded in France's republican tradition. Prior to outlining the linguistic and discursive means through which discourses of sameness are expressed, some observations are now offered regarding nationalism and national identity, and the significance of discourse in the creation of nations and interpretations of national identity is discussed.

\section{Theoretical considerations: Nations and national identity}

A number of theorists have recognised that identity (including national identity) is a socially negotiated construction with discourse playing a central role: De Fina et al. (2006: 3) point out that 'identities are seen not as merely represented in discourse, but rather are performed, enacted and embodied through a variety of linguistic and nonlinguistic means'. Scollon (1998: 252) emphasises the significance of newspaper discourse in this negotiation, noting that the social construction of identity which takes place in and through news discourse 'is a highly interdiscursive process in which identities are claimed and disputed, ratified and repudiated, displayed and masked depending on the ongoing social-interactive processes of the production of identity in discourse'. In this way, news participants (i.e. both journalists and news consumers) are co-constructers of the events in which they participate, as well as of the identities that are assigned in relation to these events. Viewing identity as a socially negotiated construction - rather than as something that is fixed or stable - thus often relies on the reproduction of shared or commonsense assumptions in relation to identity, rather than on explicit or categorical statements.

It has been pointed out that 'the construction of (ethnolinguistic) identity cannot be studied except at its boundaries, beginning with alterity or otherness' (Hastings and Manning, 2004: 293). Consequently, the 'other' can be viewed - according to Schiffrin (2006: 105) - as a 'microcosmic representation of society; other/society and self are 
interdependent because the complementary needs of each are satisfied by the other'. Likewise, Hardt-Mautner (1995: 179) assumes that 'national identity emerges very much as a relational concept, the construction of "self" being heavily dependent on the construction of "other"'. Identity can thus be considered as relational (Connolly, 2002), and placing emphasis on the common history, traits and characteristics of one in-group necessarily distinguishes it from an excluded out-group. Identity - and national identity - is as much defined by what you are not as what you are: there can be no national 'we' without a foreign 'other' (Billig, 1995). Benhabib (1996: 3) maintains that 'since every search for identity includes differentiating oneself from what one is not, identity politics is always and necessarily a politics of the creation of difference'. Referring specifically to national identity, Billig (1995: 79) argues that 'the national community can only be imagined by also imagining communities of foreigners'. Consequently, discourses of sameness, analysed below, implicitly point to difference from others, and as a result contribute to the discursive construction of a 'them' and 'us' in French society.

The discursive construction of national identity and expressions of nationalism have been viewed as a type of ideological discourse (Wodak et al., 2009); Malešević (2011: 272) argues that 'the existing categorisations of the social world tend to be taken for granted as obvious and natural [...] the appeals for preservation, maintenance and strengthening of "authentic national identities" are often nothing more than expressions of particular ideological discourses'. Nationalism, therefore, can be viewed as 'the ideology by which the world of nations has come to seem the natural world - as if there could not possibly be a world without nations' (Billig, 1995: 37). Consequently, nationalism is not simply a discussion about a nation, but rather, nationalist discourse is marked by the emotional reactions engendered in both the speaker/reader and the audience (Baruh and Popescu, 2008). Indeed, O'Doherty and Augoustinos (2008: 578) suggest that nationalist discourse can be a powerful means to promote and mobilise public support for particular political positions or projects. They further maintain (2008: 578) that 'the category of "nation" has taken over from "race" in legitimating oppressive practices towards minority groups, and indeed, as a means by which to sanitize and "de-racialize" racist discourses'. That is not to suggest that discourses relating to nationalism are necessarily malicious, but rather, 'discourses of the nation' are a means by which certain discursive actions are accomplished (Reicher and Hopkins, 2001). The analysis which follows suggests that discourses explicitly rejecting immigrant and minority groups on the grounds of race or colour are avoided in favour of discourses of sameness which presuppose a homogenous French national identity from which immigrant minorities living in the banlieues are excluded.

Before considering how a variety of lexico-grammatical and linguistic devices are used by the French press to construct a particular interpretation of the French nation and national identity, brief mention must be given to the role discourse plays in the creation of a 'nation'. As Anderson (1983) points out, nations are not only defined by fixed geographical boundaries, but are 'imagined communities', and they are cognitively and socially constructed as a 'coherent, unproblematic and homogenous community in terms of both time and space' (Bishop and Jaworski, 2003: 247). Conceptions of a nation and national identity are not determined in a top-down imposition of nationalist ideas; instead, discourse plays a central role. Hall (1995: 613) states that a national culture is a 
discourse - 'a way of constructing meanings which influences and organises both our actions and our conceptions of ourselves'. This is not to suggest that nations and national identities are fixed and stable constructs, but rather that they are fluid and changeable or 'dynamic, vulnerable and ambivalent' (Triandafyllidou and Wodak, 2003: 214), open to being re-interpreted at a given moment depending on the social context, audience, topic, etc. Wodak et al. (2009: 4) maintain that 'national identities are [...] malleable, fragile and, frequently, ambivalent and diffuse'. Thus, the following analysis does not conceive the construction of a collective French national identity as something that is cohesive and permanent, but rather, identity is viewed as being dynamic and subject to change in response to changing contexts. This is in line with Krzyżanowski's (2003: 177) comments, whereby essentialist views of (national) identity are rejected in favour of a 'dynamic' view of identity: 'the dynamism inherent in identity allows for the individual, as well as the collective, to constantly assign anew what and through what means a person or group identifies her/himself or themselves'.

Furthermore, Wodak et al. (2009: 29-30) highlight the significance of discourse - and media discourse - in the construction of national identity:

The national identity of individuals who perceive themselves as belonging to a national collectivity is manifested, inter alia, in their social practices, one of which is their discursive practices. The respective national identity is shaped by state, political, institutional, media and everyday social practices, and the material and social conditions which are their results, to which the individual is subjected. The discursive practice as a special form of social practice plays a central part both in the formation and in the expression of national identity.

The discourse of the mass media plays a significant role in the collective imagining of the nation, since 'mass media discourse, with its (re)production of ideologies in social life and its deictic delineation of Us versus Them, makes natural and unproblematic “our" place and purpose within the world of nations' (Lewis, 2008: 415). The media implicitly encourage those living in a defined geographical area to imagine other readers simultaneously consuming and reacting to the same media products, thus encouraging a sense of national belonging and comradeship. Lee et al. (2001) note the significance of the media in articulating an imagined definition of the nation, particularly in moments of crisis. They point out that:

The discursive binding of a national community shines at critical moments or around special occasions that function as a reference point and furnish a rich repertoire of cultural symbols. As public theatres, the media rank among the key institutional venues for each national community to express its shared experiences and to disclose its underlying cultural and ideological premises. (2001: 346)

Of particular interest for the current research, newspapers have been highlighted for their role in perpetuating particular constructions of the nation (e.g. Anderson, 1983; Billig, 1995). Viewing them as like a 'nationalist novel', Anderson (1983) argues that newspapers create an imagined community among a specified assembly of fellow-readers. Newspapers, by their very conception, "impl[y] the refraction of even "world events" into a specific imagined world of vernacular readers' (Anderson, 1983: 63). Consequently, 
they both anticipate and create national audiences (Law, 2001). For Billig (1995: 11), 'all the papers, whether tabloid or quality, and whether left- or right-wing, address their readers as members of the nation. They present news in ways that take for granted the existence of the world of nations'. Similarly, Funk (2013: 576) highlights the role traditionally played by the print media in creating nations and national identities; he points out that 'by simply documenting a common history at a steady pace, and for a set population, print media effectively established intangible connections between its readers while determining common characteristics for its audience'. A number of studies have examined the printed news media's role in the discursive construction of the nation (Bishop and Jaworski, 2003; Brookes, 1999; Krzyżanowski, 2003; Law, 2001; Richardson et al., 2008), and the current study contributes to this body of work by seeking to better understand the role played by the French news media in the discursive construction of the French nation. Of specific interest is how the construction of a particular view of what it means to be French facilitates the exclusion of others in society.

\section{In-group homogeneity: Discourses of sameness}

\section{Discourse of continuity}

Analysis suggests that in newspaper coverage of the 2005 riots being French is equated with the sharing of a common past/heritage in order to exclude those coming from other traditions, and assume the continuation of France as a unified and singular nation. This constructive strategy of assimilation, inclusion and continuation aims 'linguistically to create a temporal, interpersonal or spatial (territorial) similarity and homogeneity' (Wodak et al., 2009: 33) through the discursive imagining of a homogenous and united French nation. This discourse of continuity is expressed primarily through lexis, personification and modality.

For instance, Text 8, entitled 'La République muette' ['The silent Republic'], discusses the sense of grief and humiliation felt by French people in the wake of the violent scenes witnessed in the banlieues. The headline uses personification as a means of presuming intra-national similarity (Wodak et al., 2009), and it attributes human qualities (silence) to an abstract entity (the Republic). Wodak et al. (2009: 44) view personification as a type of metaphor to imply intra-national sameness and equality, and they suggest that it 'favours identification of the addressee with that of the personified collective'. This headline cues the reader to identify as a member of the collectivity signified by 'the Republic', and throughout Text 8 the importance of a collective past and present is explicitly and implicitly highlighted to create a discourse of sameness.

In Text 8 , the journalist acknowledges that there is a shared history, resulting from France's colonial policies, between French people and immigrants from $d u$ Sud ['the South']. This is particularly evident in Extracts 1 and 2:

\section{Extract 1}

Nous avons su mettre en scène, et très tôt après la guerre, notre réconciliation avec l'Allemagne; nous n'avions pas de conflit avec les principaux pays d'émigration d'avant-guerre, Italie et 
Pologne, ni d'après-guerre, Espagne et Portugal. La spécificité de l'émigration du Sud n'est pas l'islam, mais le rapport historique de la France à ces pays.

Very soon after the war we were able to stage our reconciliation with Germany; we had no conflict with the major immigration countries before the war, Italy and Poland, nor those after the war, Spain and Portugal. The specificity of emigration from the South is not Islam, but the historical relationship of France to these countries.

Repetition of the personal pronoun nous ['we'] collocating with the possessive adjective notre ['our'] presupposes a shared French past, as well as a collective remembering of a politically and historically significant event: post-War reconciliation with Germany. Wodak et al. (2009: 157) stress the significance of a common political past in the construction of national identity, noting that 'historical or mythicized recollections which are stored in the collective memory of social groups are of particular importance'. The final sentence explicitly refers to the significance of a shared colonial history as a distinctive feature of the relationship between the French and immigrants from former colonial territories, as compared to Italian, Polish, Spanish or Portuguese immigrants who also came to France in the 20th century.

This discursive pattern is also thematically foregrounded in Extract 2:

\section{Extract 2}

Comment s'approprier un imaginaire national tant que l'histoire de la décolonisation n'a pas été faite, discutée, patrimonialisée, appropriée par nous tous? Sinon, comment ces enfants de l'émigration maghrébine et d'Afrique noire peuvent-ils se reconnaître français ? Les livres d'histoire, les manuels scolaires et les ors de la République auraient dî, depuis longtemps, être convoqués à la production de cette histoire commune.

How can a national imagination be appropriated while the history of decolonisation has not $\overline{\text { been }}$ made, discussed, taken on by all of us as our cultural heritage? Otherwise, how can these children of emigration from the Maghreb and Black Africa recognise themselves as French? History books, school manuals and the golds of the Republic should long-since have been commanded to produce this common history.

The interrogative mood comment ['how'] is employed with the personal pronoun nous ['we'], implicitly addressing the reader as an accepted member of a presupposed existing nation. As in Extract 1, a politically significant event - decolonisation - is evoked to remind readers of their collective history, while the selection of the past participle of the verb patrimoine helps to reinforce a sense of shared cultural inheritance. Extract 2 explicitly articulates the desire that 'these' young people should recognise themselves as French, and uses a modal expression auraient dî ['should'] to construct this as an obligation, rather than a choice. As with Extract 1, the significance of a shared history as a distinctive feature of the relationship between the French and immigrants from former colonies is emphasised. In terms of dominant hegemonies, it is interesting that it is the French - as opposed to Algerian, Moroccan, etc. - dimension of this common history that is stressed. In line with the assimilationist approach to the integration of 
immigrants, the journalist is rearticulating a discourse of sameness which insists that to be properly considered French is to acknowledge a national similarity and homogeneity, but from a French perspective. Greater awareness of the shared historical dimension of the relationship between France and its immigrants is advocated, using a type of paternalistic discourse to suggest that 'they' cannot properly expect to feel part of the imaginaire nationale ['national imagination'] and 'recognise themselves' as being French until it is better understood how much, historically, is shared with 'us' already. Chan (2012: 369) points to the significance of emphasis on a shared common history as an indicator of in- and out-groups in discourse, noting the following:

A core aspect of national identity is a shared common history and the recollection of past events. They are important for the in-group because in the process of categorization they provide members with a common narrative in which to relate themselves to the nation, set boundaries that define what the in-group is and is not, and legitimize claims and actions.

Throughout the analytical sample, the French press remind readers of a sense of continuity through time, by drawing on strategies of assimilation, unification and continuation and by using lexical strategies to express a discourse of continuity which perpetuates a particular interpretation of French national identity and reinforces a 'them' versus 'us' divide in French society.

\section{Discourse of republicanism}

Throughout the analytical sample, there is evidence of both politicians and journalists drawing on vocabulary which evokes France's republican tradition and the related foundational principles of liberté, égalité and fraternité. Wodak et al. (2009: 83) refer to the significance of the 'foundational myth' in the discursive construction of national identity, pointing out that "narratives about nations portray concepts of history which, through certain linguistic means, identify and designate particular historical events and facts which are deemed relevant for a large number of human beings and establish chronological and causal relations'.

This discourse is expressed first by politicians using lexis, modality and in/direct quotation to construct a particular view of 'Frenchness'. For instance, Text 1 includes the following quotation from then President Chirac:

\section{Extract 3}

"Il ne peut pas exister de zone de non-droit en République et il revient aux forces de l'ordre (...) de faire appliquer la loi et de garantir à chacun le respect et la sécurité », a-t-il déclaré. [...] « Nous devons agir en nous fondant toujours sur les principes qui font notre République: chacun doit respecter la loi, chacun doit avoir sa chance. »

'Lawless zones must not exist in the Republic, and it comes to the forces of law and order [...] to ensure that the law is applied and to guarantee respect and security for everyone', he declared [...] 'We must always act based on the principles upon which our Republic is founded: everyone must respect the law, everyone must have their chance.' 
The fundamental principles upon which the French republican ideal is built are invoked and the modalised constructions il ne peut pas exister ['there cannot exist'] and nous devons ['we must'], as well as the anaphoric repetition of chacun doit ['everyone must'], permit Chirac to emphasise these constitutional rights as representing an essential component of French identity. Chirac's use of modals reinforces France's republicanism as a marker of French national identity: "Nous devons agir en nous fondant toujours sur les principes qui font notre République» ['We must always act based on the principles upon which our Republic is founded']. Additionally, in Text 4 an indirect quotation from Nicolas Sarkozy articulates a discourse of republicanism, and the incumbent Interior Minister is indirectly quoted as having used the myth of France's republican foundation to legitimise the decision to extend a State of Emergency: ${ }^{3}$

\section{Extract 4}

Nicolas Sarkozy a justifié cette prolongation par la nécessité de rétablir l'ordre républicain sur l'ensemble du territoire.

Nicolas Sarkozy justified this extension by the necessity to re-establish republican order throughout the country.

In Extract 4, the adjective républicain ('republican') is used to signify France's republican identity as an essential component required to ensure that proper law and order prevail in France. 'Republican' France is implicitly inclusive of those who have been in France for centuries, and consequently excludes post-colonial migrants and their children and grandchildren.

A lexicon that invokes France's perceived status of republican superiority is evident throughout the analytical sample, which can be viewed as a typical form of national selfglorification and positive self-presentation (Tekin, 2010; Van der Valk, 2003; Van Dijk, 1997). There are numerous references to French political history and the republican tradition, as seen, for example, in Extract 5:

\section{Extract 5}

Ils nous font regretter que la République ne soit pas plus "girondine " [...] Dans notre monarchie républicaine, il n'est pas indifférent que des désordres aient surgi alors que le sommet de l'État s'est trouvé affaibli.

They make us regret that the Republic is not more 'Girondist' [...] In our republican monarchy, it cannot be ignored that the disorder erupted while the head of the State found itself weakened.

This extract is taken from an editorial published in Le Monde (Text 6), which considers the various problems facing contemporary French society, as revealed by the violence of November 2005. In Extract 5, Le Monde editor Jean-Marie Colombani reminds readers of the significance of the French republican tradition as a defining feature of in-group identity, using the subjunctive mood with the comparative adjective plus to refer to France's supposed failure to be more girondine. ${ }^{4}$ The same article presents France as 
indisputably notre monarchie républicaine ['our republican monarchy'], once more using political tradition to suggest a unified homogenous French identity, emphasised by the possessive adjective notre ['our']. In this article (Text 6), Le Monde editor Colombani uses a republican discourse to reinforce a sense of 'social cohesion' (Lamizet, 1996), which has the simultaneous effect of excluding those who don't share this republican tradition. Furthermore, throughout the analytical sample, the abstract notion of a French model - le «modèle français» - is repeated (e.g. Text 2, Text 6, Text 9, Text 16), implying a particular French identity grounded in the constitutional ideals of liberté, égalité and fraternité.

Thus, textual analysis reveals that across the variety of news sources there is a preoccupation with France's traditional republican roots as a defining feature of 'our' sameness and superiority as a homogenous and unified group. Tekin's (2010: 160) analysis of French political discourse relating to Turkey's accession to the European Union establishes the presence of a discourse of national self-glorification, pointing out that:

Positive references praising France and myths of Frenchness, French culture, French Enlightenment, French republicanism, and France's exceptional role in the world as well as in Europe are all found to be quite common in the discourse of the speakers of almost all political convictions.

By referring to France's republican history and the constitutional ideals of liberté, égalité and fraternité as representing France's 'year zero' (Edwards, 2012), the French press and politicians emphasise a definition of Frenchness which necessarily excludes those from alternative political traditions and those who cannot be described as belonging to this definition of Frenchness, that is immigrant minorities living in the banlieues.

\section{Discourse of nationalism: The 'editorial we'}

In three texts in the analytical sample (Texts 3,6 and 9), national homogeneity is assumed and reproduced through use of the personal pronouns nous and $o n^{5}$ ['we/us'] and the possessive adjectives notre/nos ['our'] to articulate what can be called an 'editorial we'. The 'editorial we' can be simultaneously exclusive and inclusive, depending on whether 'we' is taken to be inclusive of the reader as well as the writer (Fairclough, 2001). It has been pointed out that:

National newspapers by definition are nationally distributed, and although there may be differences of age, gender, region, social class and ethnicity even within the readership of individual titles, the limit is that of the nation. So it is within these contexts that the 'we' and 'us' in these articles can be understood as referring to the nation. (Brookes, 1999: 255)

The significance of pronoun usage in discourse was discussed earlier, and it is important to remember Fortanet's (2004: 46) observation that 'in the negotiation of meaning that is always present between the person issuing a message and the person receiving the message one of the key elements is the reference of the personal pronouns'. The following discussion shows how personal pronouns are used by the French press, particularly using the editorial genre, to speak to and for the French people, and by so doing it often 
assumes national singularity and homogeneity. Billig (1995: 115) describes this as 'the nationalised syntax of hegemony', and using personal pronouns in this way allows newspaper editors and commentators to draw on expressions of nationalism as a means of emphasising in-group solidarity and, by extension, out-group exclusion.

Three articles in the analytical sample provide numerous examples of the significance of pronouns in the discursive construction of French nationalism, and, interestingly, two are editorials while the third is an opinion/commentary written by a non-journalist. Editorials are particularly significant from an ideological perspective since they offer the possibility to 'legitimize particular constructions of the social and political world over others' (Trew, 1979: 140). Additionally, Van Dijk (1989: 235) points out that the editorial genre necessarily requires the summarising or recapitulating of events, but this 'summarising, selection, and focusing presuppose ideologically framed opinions'. The following analysis highlights how in their summary and selection of events for discussion, both editorials analysed (Texts 6 and 9) construct France as a unified and homogenous society sharing certain fundamental values and ideals. Particular focus is placed on the deictic pointing of pronouns in order to better understand how discourses of sameness are created through the assumption of national singularity and homogeneity.

Beginning with Text 6, an editorial entitled 'Après le choc' ['After the shock'] from Le Monde, consider Extract 6:

\section{Extract 6}

Discrimination : telle est la véritable urgence. Nous sommes face à la réalité des résistances que nous opposons à notre propre diversité.

Discrimination: this is the real emergency. We are facing the reality of resistance which we are opposing to our own diversity.

Here, editor Jean-Marie Colombani is critical of the discrimination which exists in French society; however, repetition of the personal pronoun nous ['we'] emphasises his construction of French identity as singular. Repetition is recognised as an 'intensifying' strategy in the discourse-historical approach (DHA) (Reisigl and Wodak, 2009), used to encode emotions and for emphasis; in Extract 6 the repetition of nous reinforces the presumption of a shared national identity. This is also evident in Extract 7, referring to the role of mayors in French society:

\section{Extract 7}

Ils ont aidé à la prise de conscience nationale, au-delà des violences. Ils nous font regretter que la République ne soit pas plus " girondine».

They helped with the awakening of a national consciousness, beyond the violence. They make us regret that the Republic is not more 'girondist'.

French mayors are praised for ensuring the awakening of the 'national consciousness' as a result of the urban violence, and the personal pronoun nous ['us'] collocating with 
the strong emotive verb regretter ['to regret'] assumes an intra-national sameness in French society. Synonymously referring to France as la République ['the Republic'] reinforces the republican discourse discussed above. Furthermore, throughout the article the personal pronoun nous ['we/us'] and possessive adjective notre ['our'] are repeated:

Extract 8

notre modèle social-colbertiste

our social-colbertist model

notre monarchie républicaine

our republican monarchy

nous savons bien que là est la question centrale de la société

française

we know well that this is the central question of French society

Le Monde is purporting to have the authority to speak for the French people - or, to use Billig's (1995: 114) words, to 'stand in the eye of the country'. Mulderrig (2012: 708) points out that the deictic choice of the pronoun 'we' always entails 'a particular demarcation of participatory boundaries in the "discourse world" created in texts; of speakers' and hearers' relative positions to the events described and their involvement with them'. For Le Monde editor Colombani, the 'discourse world' created is one which assumes national homogeneity. His closing comments in the article evidence many of the strategies already discussed in the discursive construction of French national identity: the anaphoric repetition of temporal markers - en 1984 . . , en 1995 . . , en 2005 . . (in 1984..., in 1995..., in $2005 \ldots$... - emphasises the historical dimension associated with French identity, along with explicit reference to the constitutional ideals of liberté, égalité and fraternité which underpin shared French values. Dissimilarity in French society is not considered and instead 'we' are all assumed to have been obliged to feel similarly:

\section{Extract 9}

En 1984, deux millions de personnes avaient défilé de Versailles à Paris, au nom de la liberté; en 1995, le pays frôlait la paralysie au nom de l'égalité. En 2005, c'est de fraternité qu'il s'agit. Les "violences urbaines" nous ont obligé à dépasser une fausse confiance dans une politique de la ville mise à mal, pour prendre conscience de la nécessité de réhabiliter une République digne de ce nom.

In 1984, two million people marched from Versailles to Paris, in the name of liberty; in 1995, the country was close to paralysis in the name of equality. In $20 \overline{05}$, it is fraternity that is involved. 'Urban violence' has obliged us to overcome a false confidence in an urban policy that has been undermined, to become aware of the need to rehabilitate a Republic worthy of this name.

This editorial, published on 29 November as the violence had predominantly abated, purports to highlight the 'difficulties' facing modern France, and it acknowledges that 
discrimination is a feature of French society. However, it reinforces a particular exclusive view of French society, using the editorial format to accentuate nationalist sentiments and the view that there is a singular French identity which 'we' share, without consideration for dissimilarity or variation.

Similar discursive patterns are evident in an editorial entitled 'Tourner la page' ['Turn the page'] (Text 9), an article which projects a positive future for a French nation recovering from a variety of traumatic events during 2005. The imperative mood rappelonsnous ['let us recall'] is used in the opening sentences to establish supposed authority to speak as representatives of the French people, and references to pivotal events and decisions taken by les français ['the French'] reinforce a taken-for-granted national 'us'. For example:

\section{Extract 10}

le «non» des français au traité constitutionnel pour l'Europe

the French 'no' to the European constitutional treaty

les Français voient se gripper la construction européenne dont leur pays avait été le principal moteur depuis un demi-siècle

the French are witnesses to the seizing up of the European construction behind which their country was the principal driving force for half a century

Additionally, the personal pronouns nous and on ['we/us'] are used throughout to presuppose French solidarity, as in the following examples:

\section{Extract 11}

La crise des banlieues ébranle la confiance que nous mettions dans les vertus " intégratrices » de notre modèle social

The crisis in the suburbs undermines the confidence that we put in the 'inclusive' virtues of our social model

on a changé de gouvernement après le "non » au référendum we changed government after the 'no' in the referendum

nous ne parvenons toujours pas à l'atteindre... we do not always manage to reach...

aucune de ces déceptions ne doit nous décourager none of these deceptions should discourage us

As with the editorial published in Le Monde, Ouest France addresses its readership as a united and homogenous group, making extensive use of the editorial 'we' to address readers as members of an inclusive group. Wodak et al. (2009: 38) propose the strategy of 'autonomisation' for the discursive construction of national identity, maintaining that 
'presupposition/emphasis on national autonomy and independence' is a typical means of presupposing a singular national identity. This strategy is evident in Extract 12:

\section{Extract 12}

Certains le pensent, observant que, à nos portes, le chancelier Schröder a provoqué des élections anticipées (qu'il a d'ailleurs perdues) après un lourd échec dans un scrutin régional. Le président français - qui a sans doute ses raisons - en a décidé autrement chez nous.

Some people think it, observing that, at our doors, Chancellor Schröder brought about early elections (which he also lost) after a heavy defeat in regional elections. The French president - who undoubtedly has his reasons - decided otherwise at home.

Here, the actions of the French are contrasted with those of the Germans, with emphasis placed on the different decisions taken by 'us'. Throughout the article, the reference point of the deictic expressions referring to 'we' or 'us' is implicit; as Petersoo (2007: 427) uncovered in her analysis of national deixis in the Scottish print media, "whether [a] homogenous ingroup exists in the "real" world or not, is not important - debates about [...] national identity take nationness as given'. The two articles just considered (Texts 6 and 9) emphasise a discourse of nationalism to ensure positive identification by its readership, which simultaneously assumes and reproduces homogeneity. As a result, discourses of sameness are created which provide readers with 'a convincing point of self-reference' (Bishop and Jaworski, 2003: 267) which in turn reinforces in-group togetherness and homogeneity. However, such straightforward interpretations of who 'we' are are not always possible, particularly given the complex French social situation discussed earlier. Consequently, it is hardly surprising that one article in the analytical sample (Text 3) offers an example of what Petersoo (2007) terms the 'wandering we'.

Text 3 provides examples of a counter-discourse to this prevailing discourse of sameness and the construction of a homogenous national identity. This article was written by Salem Kacet - a self-declared 'integrated immigrant' of North African origin - and published in the centre-right conservative newspaper Le Figaro. As the forthcoming analysis reflects, Kacet's use of the personal pronoun nous allows him to simultaneously position himself as being a member of both the in-group and, at the same time, the out-group. Petersoo (2007: 429) refers to this notion as the 'wandering we': 'it is not a single type of "we" but rather a particular usage that can be traced within a whole paragraph or whole article'. Consider first Extract 13:

\section{Extract 13}

Nous sommes nombreux, nous que l'on nomme Français issus de l'immigration, à observer, avec attention et dépit, les embrasements réguliers des "banlieues 》. Sans aucune surprise. Voilà des années que beaucoup d'entre nous lancent des alertes, des mises en garde, des SOS qui ne sont pas entendus, ou pas vraiment pris au sérieux. Voilà des années que nous écoutons les uns et les autres discourir à l'infini sur l'immigration, sur l'intégration, sur la montée des communautarismes, sur l'intégrisme, sur les quartiers, sur ceci, sur cela. 
There are a lot of us, we who are called French people of immigrant origin, who have observed, carefully and closely, the regular burnings in the 'suburbs'. Without any surprise. For many years a lot of us launch alerts, warnings, SOS which are not heard, or are not entirely taken seriously. For many years we are listening to all and sundry endlessly discuss immigration, integration, the rise in communitarianism, fundamentalism, the neighbourhoods, this, that ...

In Extract 13, nous ['we'] refers to Français issus de l'immigration ['French people of immigrant origin'], a group defined in terms not of what they are, but of what they are not - 'real' French citizens. Their identity is assigned by an unspecified outsider, presented using the passive voice on as an implicit reference to unspecified human animate - nous que l'on nomme Français issus de l'immigration ['those who are called French people of immigrant origin']. This power to name and categorise a certain group of people positions those with the authority to categorise as the legitimator of group membership and consequently excludes the nominated group as having a role to play in the definition and elaboration of the categories of social membership. Within this specified group (French immigrants), Kacet hints at internal othering (Petersoo, 2007), suggesting a sub-category of the out-group of which he is a member: he states that beaucoup d'entre nous lancent des alertes, des mises en garde . . . ['a lot of us launch alerts, warnings...']. Thus, the out-group is further divided into those who attempt to play an active role in French society and, by implication, those who do not.

Later in the article, Kacet states the following in Extract 14:

\section{Extract 14}

Aujourd'hui, il est dans la représentation, qu'il le veuille ou pas, d'une France qui aspire à vivre normalement, dans un pays où chacun doit apprendre les valeurs de respect et de solidarité, dans un pays pacifié, reconnaissant une place pour chacun de ses enfants. Et dans les " quartiers », tous sont attentifs à la façon dont nous sortirons de cette crise qui dure depuis trente ans. A la façon dont nous allons reconstruire une France plus solidaire, plus fraternelle.

Today, it is in the representation, whether it is liked or not, of a France which aspires to live normally, in a country where everyone must learn the values of respect and solidarity, in a country at peace, recognising a place for each one of its children. And in the 'neighbourhoods', everyone is aware of the means by which we will emerge from this crisis which has lasted more than thirty years. Of the means by which $\overline{\text { we }}$ will rebuild a more united and fraternal France.

In Extract 14, the deictic pointing of the personal pronoun nous ['we/us'] and indefinite subject pronoun tous ['everyone'] is interesting: the immediate co-text refers to 'a France' which is trying to 'live normally', to learn the values of respect and solidarity, and recognising the place for 'all' its children, the journalist Kacet expresses a desire that 'we' will emerge from this crisis and 'rebuild' France; the implication is that the deictic referents of nous are assigned an active role in the future of France and consequently are members of the in-group in French society. The role assigned to nous in Extract 14 contrasts with the marginalised and excluded role in Extract 13 prior. Additionally, placing the noun quartiers ['neighbourhoods'] within inverted commas suggests its status as a contested word in French discourse. However, the proceeding indefinite pronoun tous 
['everyone'] raises a certain amount of ambiguity as to whether Kacet is placing himself and other immigrants within this group. Such ambiguity regarding the place of immigrants in French society and their identity within the context of a French national identity reflects the difficulties created by the assimilationist model of integration. As Bellier (2008: 136-137) points out in relation to the French model of integration:

[it] does not contemplate the actual inequalities of status existing between the different groups as collective entities, as long as individuals are entitled with the same formal rights. In real life, there are de facto differences between nationals born within the nation, naturalized French nationals who had to apply for French citizenship, and first/second/third-generation migrants who may or may not have adopted French nationality, even though all of these people are given the possibility to identify with the unitary model of the Republic.

Thus, Text 3 is an example of how news discourse is used to construct a definition of French national identity that is far from straightforward in the context of multicultural France. It shows how there are counter-discourses running throughout the analytical sample which challenge this hegemonic interpretation of French national identity. Petersoo (2007: 432) makes similar observations in her analysis of national deixis in the UK media representations of Scottish national identity, noting that "there is no simple and banal national "we" in the media, but a kaleidoscope of different "we"s'.

\section{Conclusion}

This article aimed to question representations of French national identity and to uncover how the French printed news media position immigrant minority groups living in the banlieues as the out-group in relation to mainstream French society (the in-group) in a sample of 16 newspaper texts reporting on incidents of French urban violence in 2005. It identified discourses of sameness and showed how within these discourses a particular interpretation of French national identity is posited which implicitly excludes minority groups, in particular, post-colonial migrants living in the banlieues. The incidents of 2005 represented a time of enormous crisis in France, resulting in the declaration of a state of emergency and the introduction of curfews. It has been observed that moments of crisis represent 'a fundamental threat to the very stability of the system, a questioning of core assumptions and beliefs, and risk to high priority goals, including organizational image [...] and ultimately survival' (Seeger and Ulmer, 2002: 126). The French press responded to the threat posed to their national model and national identity by drawing on simultaneously inclusionary and exclusionary discourses of sameness. The othering of those living in the banlieues and ostensibly responsible for the riots means that the civil disturbances are not therefore reflective of 'our' national character, and consequently the urban violence can be explained away as the result of a fundamental difference between 'them' and 'us'. As a result, dominant hegemonies do not need to be questioned in light of these traumatic events and existing social hierarchies are reproduced which position immigrant minority groups in a subjugated position vis-a-vis majority French society.

The textual analysis has revealed how discourses of sameness are reinforced by the discursive imagining of a homogenous and unified French nation by using constructive 
strategies to emphasise the sharing of a collective past. The analysis showed how moments of historical significance - such as post-War reconciliation with Germany and decolonisation - are used by the French press to remind readers of what 'we' (mainstream French society) as a homogenous nation share. By extension, 'they' (immigrant minorities) are implicitly excluded, given that, as mentioned previously, expressions of national unity necessarily entail implicit prejudice against others. As Anderson (1983: 3) points out, 'since every search for identity includes differentiating oneself from what one is not, identity politics is always and necessarily a politics of the creation of difference'. Furthermore, Blommaert and Verschueren (1998: 117-118) argue the following in relation to the representation of a society as homogenous:

homogenism abnormalizes the presence of foreigners while normalizing the autochthonous population's negative reactions to their presence, and leads to logical solutions to 'the migrant problem' formulated in terms of a discriminatory and repressive notion of integration aimed at a (partial or complete) rehomogenization of society.

The analysis of discourses of sameness revealed that news texts reporting on the riots use discourses of continuity, republicanism and nationalism to construct a particular homogenous interpretation of French national identity which is based on a shared past and a collective Republican identity. Implicit reader awareness of in- and out-groups in French society is assumed, and news consumers are thus co-constructors in the discursive creation of 'them' and 'us' groups in the French social order. As a result, social inequalities and a distinction between majority French society and immigrant minorities are taken for granted as necessary 'background knowledge' by producers of most of the texts in the analytical sample.

The analysis of interpretations of Frenchness presented in this study corresponds to Hall's (1995) assertion that citizenship of a nation does not necessarily equate with membership of a discursively imagined national community. Many of the residents of the banlieues are notionally French citizens, but the analysis of news discourse on the 2005 riots reveals their exclusion from the discursively imagined French national community. Krzyżanowski and Wodak (2008: 2) argue that in the current post-industrial/information societies nationalism is no longer defined with regard to other nations, but increasingly 'nationalism is becoming more defensive and defined by reference to migrants and other marginalized groups'. Furthermore, Mercer (1990: 43) points out that identity becomes a particular issue at a time of crisis: 'when something assumed to be fixed, coherent and stable is displaced by the experience of doubt and uncertainty'. It is thus not surprising that news coverage of the riots prompted implicit and explicit contemplation of French national identity and how Frenchness can and should be defined. Questioning interpretations of French national identity is not always done explicitly, and a CDA methodology provided the analytical tools for examining the implicit assumptions underscoring news reporting on the riots. It has been argued throughout this study that in response to the crisis posed by the traumatic events of November 2005, the definition of French national identity imagined in news reporting on the riots does not extend to those living in the banlieues. Interpretations of what it means to be French are premised on sameness, grounded in a perceived collective experience as 'French people'. 'Frenchness' is 
inferred based on a presumed republican identity stemming from the principles of liberté, égalité and fraternité as espoused during the French Revolution. The assumption of a 'them' and 'us' emerges across all news sources with the implicit understanding that 'we' are majority French society and 'they' are anything that falls outside this definition of the imagined French community, including - and in particular - immigrant minorities living in the banlieues.

\section{Funding}

This work was supported by the Irish Research Council Government of Ireland Postgraduate Scholarship Scheme, 2010-2013; and the School of Languages, Literature, Culture and Communication, University of Limerick, Ireland.

\section{Notes}

1. Body-Gendrot (Body-Gendrot, 2010: 657) summarises the banlieues as follows: 'highrisk zones characterized by the isolation and concentration of numerous first- and secondgeneration immigrants living in massive public housing projects or in dilapidated private homes devoid of adequate public services'.

2. Initially, the police denied that the teenagers had been the subject of a pursuit, but later admitted that they had been in the area seeking suspects in relation to a break-in in a nearby building site. It subsequently emerged also that when the police became aware that the youths had entered the power station, they failed to inform EDF (the electrical suppliers), who may have been able to intervene and prevent the deaths (for a more detailed discussion, see Moran, 2012: 10-12; Mucchielli, 2009: 734-736).

3. Legislation enacted during the Algerian War in 1955 was used to declare a state of emergency on 7 November, granting prefects the right to declare curfews, imprison people without charge and prohibit people from travelling or gathering in public. This state of emergency was officially lifted on 3 January 2006, although the rioting had largely subsided by 17 November.

4. This is a reference to the Girondist - so-called as they originated in the Gironde region - a political faction in the Legislative Assembly and the National Convention during the French Revolution.

5. Tekin's (2010: 158) analysis of French political discourse notes that 'by employing the indefinite pronoun "On", French speakers leave blank the subject of the utterance and [...] become inolved in a strategy of implicitness'. In the case of the French printed news media reporting on the 2005 riots, it can be argued that there is an implicit assumption of national homogeneity in the referent of on used in editorials.

\section{References}

Allan S (1998) News from NowHere: Televisual news discourse and the construction of hegemony. In: Bell A and Garrett P (eds) Approaches to Media Discourse. Oxford: Blackwell, pp. 105-141.

Anderson B (1983) Imagined Communities: Reflections on the Origins and Spread of Nationalism. London: Verso.

Baruh L and Popescu M (2008) Guiding metaphors of nationalism: The Cyprus issue and the construction of Turkish national identity in online discussions. Discourse \& Communication 2: 79-96.

Bellier I (2008) Multiculturalization of societies: The state and human rights issues. In: Delanty G, Wodak R and Jones P (eds) Identity, Belonging and Migration. Liverpool: Liverpool University Press, pp. 134-151. 
Benhabib S (1996) Democracy and Difference: Contesting the Boundaries of the Political. Princeton, NJ: Princeton University Press.

Benwell B and Stokoe E (2006) Discourse and Identity. Edinburgh: Edinburgh University Press.

Billig M (1995) Banal Nationalism. London: SAGE.

Bishop H and Jaworski A (2003) We beat 'em': Nationalism and the hegemony of homogeneity in the British press reportage of Germany versus England during Euro 2000. Discourse \& Society 14: 243-271.

Blommaert J and Verschueren J (1998) Debating Diversity: Analysing the Discourse of Tolerance. London: Routledge.

Body-Gendrot S (2010) Police marginality, racial logics and discrimination in the banlieues of France. Ethnic and Racial Studies 33: 656-674.

Brookes R (1999) Newspapers and national identity: The BSE/CJD crisis and the British press. Media, Culture \& Society 21(2): 247-263.

Caldas-Coulthard C (2007) Cross-cultural representation of 'otherness' in media discourse. In: Weiss G and Wodak R (eds) Critical Discourse Analysis: Theory and Interdisciplinarity. Basingstoke: Palgrave Macmillan, pp. 272-296.

Chan M (2012) The discursive reproduction of ideologies and national identities in the Chinese and Japanese English-language press. Discourse \& Communication 6: 361-378.

Chouliaraki L and Fairclough N (1999) Discourse in Late Modernity: Rethinking Critical Discourse Analysis. Edinburgh: Edinburgh University Press.

Cohen S (1972) Folk Devils and Moral Panics. London: Routledge.

Collovald A (2001) Des désordres sociaux à la violence urbaine [Social disorder to urban violence]. Actes de la Recherche en Sciences Sociales [Proceedings of Social Science Research] 136-137: 104-113.

Connolly WE (2002) Identity/Difference: Democratic Negotiations of Political Paradox. Minneapolis, MN: University of Minnesota Press.

Crawford E (2011) Them and us: Why they are nationalists and we are not. An analysis of journalists' language in relation to others. Journalism 13: 620-638.

De Cillia R, Reisigl M and Wodak R (1999) The discursive construction of national identities. Discourse \& Society 10: 149-173.

De Fina A, Schiffrin D and Bamberg M (2006) Introduction. In: De Fina A, Schiffrin D and Bamberg M (eds) Discourse and Identity. Cambridge: Cambridge University Press, pp. 1-23.

Dekavalla M (2010) Tax, war and waiting lists: The construction of national identity in newspaper coverage of general elections after devolution. Discourse \& Society 21: 638-654.

Edwards GO (2012) A comparative discourse analysis of the construction of 'in-groups' in the 2005 and 2010 manifestos of the British National Party. Discourse \& Society 23: 245-258.

Erjavec K (2001) Media representation of the discrimination against the Roma in Eastern Europe: The case of Slovenia. Discourse \& Society 12: 699-727.

Fairclough N (1992) Discourse and Social Change. Cambridge: Polity.

Fairclough N (1995) Media Discourse. London: Edward Arnold.

Fairclough N (2001) Language and Power. Harlow: Longman.

Fang Y-J (1994) Riots and demonstrations in the Chinese press: A case-study of language and ideology. Discourse \& Society 5: 463-481.

Fortanet I (2004) The use of 'we' in university lectures: Reference and function. English for Specific Purposes 23: 45-66.

Fowler R (1991) Language in the News: Discourse and Ideology in the Press. Oxford: Routledge.

Fowler R, Hodge B, Kress G, et al. (1979) Language and Control. London: Routledge \& Kegan Paul. 
Funk M (2013) Imagined commodities? Analyzing local identity and place in American community newspaper website banners. New Media \& Society [Space and Society] 15: 574-595.

Garcin-Marrou I (2007) Des 'jeunes' et des 'banlieues' dans la presse de l'automne 2005: entre compréhension et relégation ["Youth" and the "suburbs" in press coverage of Autumn 2005: between understanding and relegation]. Espaces et Sociétés 1-2: 23-37.

Hall S (1995) The question of cultural identity. In: Hall S, Held D, Hubert D, et al. (eds) Modernity: An Introduction to Modern Societies. Oxford: Blackwell, pp. 595-634.

Hardt-Mautner G (1995) 'How does one become a good European?' The British press and European integration. Discourse \& Society 6: 177-205.

Hargreaves AG (1996) A deviant construction: The French media and the banlieues. Journal of Ethnic and Migration Studies 22: 607-618.

Hart C (2012) Event-construal in press reports of violence in two recent political protests: A cognitive linguistic approach to CDA. Journal of Language and Politics 12: 400-423.

Hartley J (1982) Understanding News. London: Routledge.

Hastings A and Manning P (2004) Introduction: Acts of alterity. Language \& Communication 24: 291-311.

Kelly-Holmes H and O'Regan V (2004) “The spoilt children of Europe”: German press coverage of the Nice Treaty referenda in Ireland. Journal of Language and Politics 3(1): 81-116.

Kokoreff M and Lapeyronnie D (2013) Refaire La Cité [Rebuild the City]. Paris: Seuil.

Krzyżanowski M (2003) 'My feelings are not only based on the fact that I live in Europe': On the new mechanisms in European and national identification patterns emerging under the influence of EU enlargement. Journal of Language and Politics 2: 175-204.

Krzyżanowski M and Wodak R (2008) The Politics of Exclusion: Debating Migration in Austria. New Brunswick, NJ: Transaction.

Lamizet B (1996) The media in France. In: Weymouth A and Lamizet B (eds) Markets and Myths: Forces for Change in the European Media. London: Longman, pp. 173-205.

Law A (2001) Near and far: Banal national identity and the press in Scotland. Media, Culture \& Society 23: 299-317.

Lee CC, Pan Z, Chan JM, et al. (2001) Through the eyes of US media: Banging the democracy drum in Hong Kong. Journal of Communication 51: 345-365.

Levasseur B (2010) Journalism at the margins: Afrika as a case of ethnic minority press and alternative representations of the Banlieue. Web Journal of French Media Studies 8. Available at: http://wjfms.ncl.ac.uk/LEVASSEUR.pdf (accessed 24 January 2013).

Lewis SC (2008) News, nationalism and the imagined community: The case of bilingual journalism in Spain. Journalism Studies 9: 409-428.

Malešević S (2011) The chimera of national identity. Nations and Nationalism 17: 272-290.

Mercer K (1990) Welcome to the jungle: Identity and diversity in postmodern politics. In: Rutherford J (ed.) Identity: Community, Culture, Difference. London: Lawrence \& Wishart, pp. $43-71$.

Moirand S (2010) Le choc des discours dans la presse française: de la crise des banlieues à celle des universités (novembre 2005, mars 2006) [The clash of discourses in the French press: from the crisis in the suburbs to the universities (November 2005, March 2006)]. In: Fornasiero J and Mrowa-Hopkins C (eds) Explorations and Encounters in French. Adelaide, SA, Australia: University of Adelaide Press, pp. 35-76.

Moran M (2012) The Republic and the Riots: Exploring Urban Violence in French Suburbs, 2005-2007. Oxford: Peter Lang.

Mucchielli L (2009) Autumn 2005: A review of the most important riot in the history of French contemporary society. Journal of Ethnic and Migration Studies 35: 731-751. 
Mucchielli L and Aït-Omar A (2006) Les émeutes de novembre 2005: les raisons de la colère [The November 2005 riots: the reasons for the violence]. In: Mucchielli L and Le Goaziou V (eds) Quand les Banlieues Brûlent: retour sur les émeutes de novembre 2005 [When the Suburbs Burn: return to the riots of November 2005]. Paris: La Découverte, pp. 11-35.

Mulderrig J (2012) The hegemony of inclusion: A corpus-based critical discourse analysis of deixis in education policy. Discourse \& Society 23: 701-728.

Neiger M and Rimmer-Tsory K (2013) The war that wasn't on the news: 'In-group nationalism' and 'out-group nationalism' in newspaper supplements. Journalism 14: 721-736.

Neveu E (2002) The local press and the farmers' protests in Brittany: Proximity and distance in the local newspaper coverage of a social movement. Journalism Studies 3: 53-67.

O'Doherty K and Augoustinos M (2008) Protecting the nation: Nationalist rhetoric on asylum seekers and the 'Tampa'. Journal of Community \& Applied Social Psychology 18: 576-592.

Oktar L (2001) The ideological organization of representational processes in the presentation of us and them. Discourse \& Society 12: 313-346.

Peeters S (2010) 'The suburbs are exploding': Metaphors as framing devices in the French suburban crisis coverage. Belgian Journal of Linguistics 24: 103-119.

Peeters S (2012) La couverture médiatique de la « crise des banlieues »: métaphores, représentations et l'apport indispensable du cotexte [Media coverage of the 'crisis in the suburbs': metaphors, representations and the essential support of co-text]. RJC Cotexte, contexte, situation [RJC Co-text, Context, Situation], 9 January. Available at: http://corela.edel.univ-poitiers.fr/ index.php?id=2079 (accessed 26 November 2012).

Petersoo P (2007) What does 'we' mean? National deixis in the media. Journal of Language and Politics 6: 419-436.

Pietikäinen S (2001) On the fringe: News representations of the Sami. Social Identities 7: 637-657.

Reicher S and Hopkins N (2001) Self and Nation: Categorization, Contestation and Mobilization. London: SAGE.

Reisigl M and Wodak R (2009) The discourse-historical approach (DHA). In: Wodak R and Meyer M (eds) Methods of Critical Discourse Analysis, 2nd edn. London: SAGE, pp. 87-121.

Richardson JE (2007) Analysing Newspapers: An Approach from Critical Discourse Analysis. Basingstoke: Palgrave Macmillan.

Richardson JE, Huckerby S and Williams M (2008) Nation, culture and identity in a Frenchlanguage Corsican newspaper. Journalism Studies 9: 561-577.

Schiffrin D (2006) From linguistic reference to social reality. In: De Fina A, Schiffrin D and Bamberg M (eds) Discourse and Identity. Cambridge: Cambridge University Press, pp. 103-131.

Scollon R (1998) Mediated Discourse as Social Interaction: A Study of News Discourse. London: Longman.

Sedel J (2009) Les Médias et la Banlieue Media and the Suburb. Latresne: Le Bord de l'Eau.

Seeger MW and Ulmer RR (2002) A post-crisis discourse of renewal: The cases of Malden Mills and Cold Hardwoods. Journal of Applied Communication Research 30: 126-143.

Simmons K and Lecouteur A (2008) Modern racism in the media: Constructions of 'the possibility of change' in accounts of two Australian 'riots'. Discourse \& Society 19: 667-687.

Simpson PM (1993) Language, Ideology and Point of View. London: Routledge.

Tekin BÇ (2010) Representations and Othering in Discourse: The Construction of Turkey in the EU Context. Amsterdam: John Benjamins.

Thetela P (2001) Critique discourses and ideology in newspaper reports: A discourse analysis of the South African press reports on the 1998 SADC's military intervention in Lesotho. Discourse \& Society 12: 347-370. 
Trew T (1979) 'What the papers say': Linguistic variation and ideological difference. In: Fowler R, Hodge B, Kress G, et al. (eds) Language and Control. London: Routledge \& Kegan Paul, pp. 117-156.

Triandafyllidou A and Wodak R (2003) Conceptual and methodological questions in the study of collective identity: An introduction. Journal of Language and Politics 2: 205-225.

Van der Valk I (2003) Political discourse on ethnic minorities: A comparison of the right and extreme right in the Netherlands and France (1990-97). Ethnicities 3: 183-213.

Van Dijk T (1988) News as Discourse. Hillsdale, NJ: Lawrence Erlbaum.

Van Dijk T (1989) Race, riots and the press: An analysis of editorials in the British press about the 1985 disorders. Gazette 43: 229-253.

Van Dijk T (1996) Discourse, power and access. In: Caldas-Coulthard CR and Coulthard M (eds) Texts and Practices: Readings in Critical Discourse Analysis. London: Routledge, pp. 84-104.

Van Dijk T (1997) Political discourse and racism: Describing others in western parliaments. In: Riggins HS (ed.) The Language and Politics of Exclusion: Others in Discourse. Thousand Oaks, CA: SAGE, pp. 31-64.

Van Dijk T (1998) Ideology: A Multidisciplinary Approach. London: SAGE.

Van Dijk T (2006) Ideology and discourse analysis. Journal of Political Ideologies 11: 115-140.

Wodak R, De Cillia R, Reisigl M, et al. (2009) The Discursive Construction of National Identity. Edinburgh: Edinburgh University Press.

\section{Author biography}

Laura Costelloe recently completed her doctoral thesis with the support of the Irish Research Council at the School of Languages, Literature, Culture \& Communication, University of Limerick, Ireland. Her doctoral thesis examines newspaper discourses surrounding French urban violence specifically the 2005 civil disturbances - and combines critical discourse analysis and corpus linguistics in an analysis of the discursive functioning of ideology and power in French news reporting on the riots. Her research interests include: the combination of critical discourse analysis and corpus linguistics in the analysis of discourse, media discourses and modern French culture and society. 